\title{
Effects of Exogenous Application of Indole-3-Butyric Acid on Maize Plants Under Cadmium Stress
}

Kristína Šípošová

Slovenská akadémia vied: Slovenska akademia vied

Eva Labancová

Slovenská akadémia vied: Slovenska akademia vied

Danica Kučerová

Slovenská akadémia vied: Slovenska akademia vied

Karin Kollárová

Slovenská akadémia vied: Slovenska akademia vied

Zuzana Vivodová ( $\sim$ zuzana.vatehova@savba.sk)

Institute of Chemistry, Slovak Academy of Sciences https://orcid.org/0000-0002-6372-1257

\section{Research Article}

Keywords: antioxidant enzymes, auxin, growth, indole-3-butyric acid, maize, nutrients, reactive oxygen species

Posted Date: April 28th, 2021

DOI: https://doi.org/10.21203/rs.3.rs-416113/v1

License: (c) (i) This work is licensed under a Creative Commons Attribution 4.0 International License. Read Full License 


\section{Abstract}

Exogenously-applied auxins can alleviate the toxicity of various metals and improve a plant's tolerance to stress. Cadmium (Cd) is a toxic metal that has a wide range of negative effects on plants. The mechanisms that result in the positive effects of auxins on stressed plants are still not fully understood. In the present study, we found that the application of indole-3-butyric acid (IBA) in concentration $10^{-9} \mathrm{M}$ had positive effect on the plants cultivated in the presence of $\mathrm{Cd}$. IBA caused changes in the growth and morphology of the maize also under non-stress conditions; hence, we were able to select three concentrations of IBA $\left(10^{-7} \mathrm{M}\right.$ as inhibitory, $10^{-8} \mathrm{M}$ as non-effective, and $10^{-11} \mathrm{M}$ as stimulatory). Cadmium treatment increased the concentration of $\mathrm{H}_{2} \mathrm{O}_{2}$ and the activity of the antioxidant enzymes: superoxide dismutase (SOD), ascorbate peroxidase (APX), and catalase (CAT), while IBA (10 $\left.{ }^{-9} \mathrm{M}\right)$ ameliorated its negative effects. IBA affected the content of macronutrients and micronutrients in roots in relation to the concentration of applied IBA and the presence of $\mathrm{Cd}$ in the solution. The heatmap visualises the differences between the $\mathrm{Cd}$ and $\mathrm{Cd}+\mathrm{IBA}$ effects on all parameters studied, and indicates the positive effects of IBA $\left(10^{-9} \mathrm{M}\right)$ during Cd stress.

\section{Introduction}

Cadmium (Cd) is toxic not only for the plant but also for all living organisms (Asgher et al. 2015; Hernandez-Baranda et al. 2019). The concentration of $\mathrm{Cd}$ in the environment in the last decade is increasing exponentially, mainly due contaminated sewage sludge and waste water leakage, or due to landfills (Wagner 1993; Anjum et al. 2015). Also, the excessive usage of nitrogen and phosphate fertilizer might increase the soil acidification which accelerates the absorption of Cd by plants (Huang et al. 2020). Even the low concentration of Cd in environment can be easily transferred from contaminated soils to plants, and enhanced accumulation of $\mathrm{Cd}^{2+}$ in the tissues poses a great risk to all living organisms through the food chain (Clemens et al. 2013). Once absorbed, $\mathrm{Cd}$ is retained in the human body and is toxic to kidney, respiratory and digestive systems, and can cause a bone demineralization and other diseases (Jarup and Åkkeson 2009).

Auxins are a group of plant hormones that affect and control many metabolic processes, including plant growth and plant responses to the environment (Tognetti et al. 2012). Biosynthesis, polar transport, and the generation of auxin maxima play key roles in the coordination of the plant's growth. The crosstalk between auxins and other substances, e.g. ethylene, cytokinins, gibberellin, strigolactones, is also an important part of the regulation of auxin production and transport in plants. The crosstalk between auxins and reactive oxygen species (ROS) is integrated in a complex hormonal network that controls diverse aspects of plant growth and development, such as the cell cycle, cell wall plasticity, shoot branching and flowering time, abiotic stress adaptation, and programmed cell death (Tognetti et al. 2012).

ROS, such as superoxide radicals, hydrogen peroxide, singlet oxygen, and hydroxyl radicals, are present in every plant cell because they are continuously produced as unwanted by-products of various metabolic pathways, which are mainly localized in mitochondria, chloroplasts, and nitrogen-fixing nodules (Garg and Manchanda 2009). However, the concentrations of ROS are controlled, reduced and scavenged by antioxidant enzymes (Garg and Manchanda 2009). Superoxide is converted to hydrogen peroxide $\left(\mathrm{H}_{2} \mathrm{O}_{2}\right)$ and oxygen $\left(\mathrm{O}_{2}\right)$ by superoxide dismutase (SOD, EC 1.15.1.1), and then $\mathrm{H}_{2} \mathrm{O}_{2}$ is converted to water $\left(\mathrm{H}_{2} \mathrm{O}\right)$ and $\mathrm{O}_{2}$ by ascorbate peroxidase (APX, EC 1.11.1.11), guaiacol peroxidase (EC 1.11.1.7), catalase (CAT, EC 1.11.1.6), and glutathione reductase (EC 1.8.1.7). All types of ROS are involved in the networks of signalling pathways and in the responses to environmental factors (Garg and Manchanda 2009).

Exogenously-applied auxins can alleviate Cd toxicity (Bashri and Prasad 2016), but the mechanisms of their action are still not fully understood. Bashri and Prasad (2016) found that indole-3-acetic acid (IAA) increases the activity of the ascorbate-glutathion cycle. As mentioned above, Cd decreases the uptake and accumulation of nutrients, which results in decreased plant biomass. One of the possible actions of auxins might be via an improved uptake of nutrients; however, there is little known about the effects of exogenously-applied auxins on the nutrient status of plants growing in both contaminated and non-contaminated conditions. Many studies focused on the effects IAA - natural auxin - on the antioxidant defence system and mineral nutrients, with/without presence of toxic metals (López et al. 2007; Wang et al. 2007; Bashri and Prasad 2016). However, it is not suitable as a component of fertilizers because it is known that IAA has low stability in solution and quickly degrades (Nordström et al. 1991). Furthermore, only one or non-specified concentration of auxin was used in available studies (López et al. 2007; Wang et al. 2007; Bashri and Prasad 2016).

The aims of this study were to investigate the effects of the exogenously-applied auxin indole-3-butyric acid (IBA) on the morphology and physiology of maize plants cultivated with or without $\mathrm{Cd}$. Maize is a staple food that is grown and distributed worldwide. It is grown on different soils around the world including those that are contaminated with toxic elements. For that reason, it is necessary to study the methods that could improve the growth and quality of this crop. In our experiments we chose IBA because it has higher stability in solution that IAA (Nordström et al. 1991), and also because IBA in the cells is converted to IAA in the process of $\beta$-oxidation. We determined the concentration of $\mathrm{H}_{2} \mathrm{O}_{2}$, the activity of antioxidant enzymes, and the changes in the uptake of mineral nutrients in these treatments: $\mathrm{Cd}$ treatment, one stimulatory concentration of IBA in the presence of $\mathrm{Cd}$, and in three other IBA concentrations with different effects on the growth of the maize roots cultivated without Cd.

\section{Materials And Methods}

\subsection{Plant material and cultivation}

Maize grains (Zea mays L., hybrid Almansa) were obtained from RWA Slovakia s. r. o. Bratislava, Slovakia. We prepared and cultivated the plant material according to our previous research (Šípošová et al. 2019). The grains were grown in Hoagland solution, or in Hoagland solution supplemented with IBA 
in concentrations ranging from $10^{-12} \mathrm{M}$ to $10^{-7} \mathrm{M}$, and with/without $\mathrm{Cd}\left(\mathrm{NO}_{3}\right)_{2}$ at a concentration of $50 \mathrm{mM}$, at $\mathrm{pH} 6.2$, under controlled conditions (photosynthetic photon flux of $130-140 \mu \mathrm{mol} \mathrm{m}^{-2} \mathrm{~s}^{-1}, 25 / 20^{\circ} \mathrm{C}$ temperature, 16 -hour photoperiod, and $70 \%$ humidity) for 10 days.

\subsection{Measurement of the growth parameters}

After 10 days of cultivation, the plants were harvested. The elongation of the primary roots (PR) (the difference between the final length and the initial length of PR), the branching of the PR (the length of the branched part of the PR), the number of lateral roots (LR), and the fresh and dry weight were determined. The roots were frozen in liquid nitrogen and stored at $-70^{\circ} \mathrm{C}$ until enzyme extraction. The roots used for elementary analyses were dried for 72 hours at $105^{\circ} \mathrm{C}$.

\subsection{Determination of $\mathrm{H}_{2} \mathrm{O}_{2}$}

The hydrogen peroxide $\left(\mathrm{H}_{2} \mathrm{O}_{2}\right)$ concentration was determined according to the modified method of Velikova et al. (2000). The maize roots (500 mg) were homogenized in a cold $50 \mathrm{mM}$ sodium phosphate buffer ( $\mathrm{pH} 7.0)$, then centrifuged at $5300 \mathrm{~g}$ for 10 min at $4^{\circ} \mathrm{C}$. The supernatant was diluted with $1 \mathrm{mM}$ potassium iodide in the ratio $1: 2$. The absorbance was measured spectrophotometrically at $390 \mathrm{~nm}$ and the concentration of $\mathrm{H}_{2} \mathrm{O}_{2}$ was calculated based on a standard curve.

\subsection{Determination of antioxidant enzymes activity}

The frozen roots (2.7 $\mathrm{g}$ fresh weight) were homogenised in liquid nitrogen and suspended in a $50 \mathrm{mM}$ sodium phosphate buffer (7 ml, pH 7.8 ), containing $50 \mathrm{mM}$ EDTA and protease inhibitor cocktail tablets (Roche Diagnostics $\mathrm{GmbH}$, Germany). The homogenate was centrifuged at $3800 \mathrm{~g}$ for 30 min at $4{ }^{\circ} \mathrm{C}$, and a supernatant was used to determine both the activity of the antioxidant enzymes and the concentration of soluble proteins. The latter was determined by the Bradford method, using bovine serum albumin as a standard (Bradford 1976).

The activity of SOD was determined according to Madamanchi et al. (1994) and was measured spectrophotometrically at $560 \mathrm{~nm}$. The reaction mixture contained a $50 \mathrm{mM}$ sodium phosphate buffer (1.8 ml, pH 7.8), $0.15 \mathrm{mM} \mathrm{MTT}(150 \mu \mathrm{l}), 13 \mathrm{mM}$ methionine (600 $\mu \mathrm{l}), 1 \mathrm{mM}$ EDTA (150 $\mu \mathrm{l})$, and $2 \mu \mathrm{M}$ riboflavin $(150 \mu \mathrm{l})$. The mixture was placed in sample tubes under fluorescent light $\left(50 \mu \mathrm{mol} \mathrm{m}^{-2} \mathrm{~s}^{-1}\right)$ for 15 minutes.

The activity of APX was determined according to Nakano and Asada (1981) and was measured spectrophotometrically at $290 \mathrm{~nm}$. The reaction mixture contained a $50 \mathrm{mM}$ sodium phosphate buffer ( $\mathrm{pH} 7.0), 1 \mathrm{mM}$ EDTA $(300 \mu \mathrm{l}), 0.5 \mathrm{mM}$ ascorbate $(300 \mu \mathrm{l})$, and $0.1 \mathrm{mM} \mathrm{H}_{2} \mathrm{O}_{2}(300 \mu \mathrm{l})$.

The activity of CAT was determined according to Hodges et al. (1997) and was measured spectrophotometrically at $240 \mathrm{~nm}$. The reaction mixture contained a $50 \mathrm{mM}$ sodium phosphate buffer $(2 \mathrm{ml}, \mathrm{pH} 7.8)$ and $3 \% \mathrm{H}_{2} \mathrm{O}_{2}(150 \mu \mathrm{l})$. Specific CAT activity was calculated according to Claiborne (1985).

\subsection{Determination of selected mineral nutrients}

Dried maize roots $(250 \mathrm{mg})$ were dissolved in concentrated $\mathrm{HNO}_{3}(4 \mathrm{ml})$ and $\mathrm{H}_{2} \mathrm{O}_{2}(2 \mathrm{ml})$, and the solution was heated at $220{ }^{\circ} \mathrm{C}$ under pressure at 60 bar for $20 \mathrm{~min}$. Measurements of the concentrations of macro- (Ca, K, Mg, P), micronutrients (Fe, Mn, $\mathrm{Cu}$, and $\mathrm{Zn}$ ), and $\mathrm{Cd}$ were carried out by flame atomic absorption spectrometry (AAS Perkin Elmer 1100 and 4100) and by inductively-coupled plasma mass spectrometry (ICP-MS, Thermo iCap Q) at the Institute of Laboratory Research on Geomaterials, Faculty of Natural Sciences, Comenius University in Bratislava, Slovakia. The concentrations of the macronutrients $\mathrm{N}$ and $\mathrm{S}$ were estimated by gas chromatography, using a FLASH 2000 Organic elemental analyser (CHNS-0) from Thermo Fisher Scientific, USA, at the Analytical Department, Institute of Chemistry SAS, Bratislava, Slovakia. To analyse the uptake and accumulation of mineral nutrients and $\mathrm{Cd}$ to the maize roots we calculated the content of selected nutrients and Cd per one plant.

\subsection{Heatmap}

The heatmap is a two-dimensional graphic representation of the data set in which similar values are depicted by similar colours (Sun and Li 2013). In order to create a heatmap and compare the parameters (elongation of PR, branching of PR, number of lateral roots, fresh and dry weight, activity of enzymes: APX, CAT, SOD, concentration of $\mathrm{H}_{2} \mathrm{O}_{2}$, content of nutrients: $\mathrm{Ca}, \mathrm{K}, \mathrm{Mg}, \mathrm{P}, \mathrm{N}, \mathrm{S}, \mathrm{Fe}, \mathrm{Mn}, \mathrm{Cu}, \mathrm{Zn}$ ), we recalculated the data and expressed every value of every parameter as a percentage of its corresponding control (control $=100 \%)$. The dendrograms sort the parameters and the treatments (control, IBA $\left(10^{-11} \mathrm{M}\right)$, IBA $\left(10^{-8} \mathrm{M}\right)$, IBA $\left.\left(10^{-7} \mathrm{M}\right), \mathrm{Cd}, \mathrm{Cd}+\mathrm{IBA}\right)$ according to their similarity. The heatmap was made by using function heatmap.2. from gplots package (Warnes et al. 2020) in R software 3.6.3 (2020-02-29) (R Core Team, 2020).

\subsection{Statistical analyses}

The data are displayed as mean values \pm standard error (SE). Statistical analyses followed the analysis of variance (ANOVA) and Tukey test at $P \otimes 0.05$ with R software 3.6.3 (2020-02-29). To analyse the growth parameters, the number of analysed values was 45 ( 3 repetitions of 15 samples) for every treatment. To analyse the enzyme activity and the concentration of $\mathrm{H}_{2} \mathrm{O}_{2}$, the number of analysed values was 15 ( 3 repetitions of 5 samples) for every treatment. To determine the selected mineral nutrients, the number of analysed values was 9 (3 repetitions of 3 samples) for every treatment.

\section{Results}


We tested the effects of IBA in different concentrations (range from $10^{-12} \mathrm{M}$ to $10^{-7} \mathrm{M}$ ) and determined their effects on the growth parameters (Fig. 1, Tab. 1). IBA in concentrations of $10^{-12} \mathrm{M}, 10^{-11} \mathrm{M}, 10^{-10} \mathrm{M}$ stimulated root growth compared to the control (elongation growth of PR, branching of PR the length of the branched part of PR, and number of LR). The elongation of PR increased with decreasing auxin concentration. The highest number of LR was determined in the plants treated with IBA in concentration of $10^{-11} \mathrm{M}$ (by $83.2 \%$ ) compared to the control. Only IBA in concentration of $10^{-11} \mathrm{M}$ increased the fresh weight of the roots significantly (by 21.9\%) and none of the concentrations affected their dry weights to any great extent. The concentration $10^{-9} \mathrm{M}$ had only a small stimulatory effect on branching of PR as well as on formation of lateral roots. IBA in the $10^{-8} \mathrm{M}$ concentration had minimal effects on the growth parameters. IBA in the $10^{-7} \mathrm{M}$ concentration negatively affected plant growth: inhibited the elongation of PR (by 73.2\%), decreased the number of LR (by 34.5\%), fresh and dry weight (by about 27\%) compared to the control. In the light of these results, we selected three concentrations of IBA which had different effects on maize root growth: $10^{-11} \mathrm{M}$ as stimulatory, $10^{-8} \mathrm{M}$ as non-effective, and $10^{-7} \mathrm{M}$ as inhibitory.

We ascertained that $\mathrm{Cd}$ in the $50 \mathrm{mM}$ concentration in the substrate negatively affected plant growth (Fig. 2, Tab. 2). Cd strongly inhibited elongation of PR (by $60.8 \%$ ), and decreased the number of LR (by 52.1\%) and the fresh weight (by $48.8 \%$ ) and the dry weight (by $46.3 \%$ ), when compared to the control. However, Cd stimulated branching of the primary root (by $8.1 \%$ ).

We tested the effects of IBA in the same concentrations as above (ranging from $10^{-12} \mathrm{M}$ to $10^{-7} \mathrm{M}$ ) on plants growing in the presence of Cd (Fig.2, Tab. 2). Contrary to the non-stress conditions, IBA in the $10^{-9} \mathrm{M}$ concentration had the most significant stimulatory effects on plants under $\mathrm{Cd}$ stress. IBA in this concentration stimulated the elongation of PR (by 31.8\%), the number of LR (by $30.7 \%$ ), and both the fresh weight (by $52.1 \%$ ) and the dry weight (by $57.8 \%$ ), compared to the $\mathrm{Cd}$ treatment. Concentrations which were lower or higher than $10^{-9} \mathrm{M}$ did not significantly positively affect plant growth and we concluded that these concentrations were not suitable to be efficient in the alleviation of Cd toxicity.

\subsection{Effects of IBA and Cd on the concentrations of $\mathrm{H}_{2} \mathrm{O}_{2}$ and on the activity of antioxidant enzymes in maize roots}

In our following experiments, we determined the changes in the concentration of $\mathrm{H}_{2} \mathrm{O}_{2}$ and the activities of three antioxidant enzymes (SOD, CAT, APX) in the plants that were treated with three different concentrations of IBA $\left(10^{-11} \mathrm{M}\right.$ - stimulatory, $10^{-8} \mathrm{M}-$ non-effective and $10^{-7} \mathrm{M}-$ inhibitory), Cd in a 50 $\mu \mathrm{M}$ concentration, and a combination of $\mathrm{Cd}$ and the most effective concentration of IBA $\left(10^{-9} \mathrm{M}\right)$ in alleviating the toxicity of Cd (Cd+IBA treatment).

The highest concentration of $\mathrm{H}_{2} \mathrm{O}_{2}$ was detected in the roots that had the most severe inhibition of root growth when compared to control (Fig. 3A). The application of only $\mathrm{Cd}$ resulted in the highest increase in the concentration of $\mathrm{H}_{2} \mathrm{O}_{2}$ (by $136.5 \%$ ), while the IBA $\left(10^{-7} \mathrm{M}\right.$ ) treatment increased the concentration by $40.6 \%$. Even though, the concentration of $\mathrm{H}_{2} \mathrm{O}_{2}$ was reduced considerably in the Cd+IBA treatment (2.5 times lower than in the Cd treatment), it was still higher (by 55.5\%) than in the control. We did not determine any significant differences between the control and the plants treated with other concentrations of IBA.

In plants treated only with auxin, the highest activity of all the enzymes studied was ascertained in the IBA (10-7 M) treatment (Fig. 3B, C, D). The activity of SOD, CAT, and APX increased by almost $15.3 \%, 34.1 \%$, and $22.0 \%$, respectively, when compared to control. The IBA (10-11 M) treatment resulted in a decrease in the activity of SOD (by $34.2 \%$ ). Our results indicate that the effects of IBA on enzyme activity depend on the concentration used.

In the plants that grew in the presence of Cd, the highest enzyme activity was observed in the Cd treatment (Fig. 3B, C, D). The activity of SOD, CAT, and APX increased by $69.2 \%, 34.2 \%$, and $89.0 \%$, respectively, when compared to the control. The Cd+IBA treatment decreased the activity of SOD (by $36.4 \%$ ), CAT (by $25.1 \%$ ), and APX (by 25.0\%) when compared to the Cd treatment. The activity of the enzymes in the Cd+IBA treatment reached the levels found in the control.

\subsection{Effect of IBA on the content of Cd}

In our study, exogenously-applied auxin did not affect the content of $\mathrm{Cd}$ in the roots ( $162 \mu \mathrm{g}$ per roots of one plant) when compared to the Cd treatment (168 $\mu \mathrm{g}$ per roots of one plant) (Fig. 4).

\subsection{Effects of IBA and Cd on the content of mineral nutrients}

The three IBA concentrations tested caused various changes in the content of macro- and micronutrients in roots (Tab. 3,4$)$. The IBA $\left(10^{-11} \mathrm{M}\right)$ treatment increased the content of all selected nutrients compared to the control. The content of macronutrients increased in the range between $6.3-32.6 \%$ and micronutrients in the range between $7.8-19.3 \%$. The IBA $\left(10^{-8} \mathrm{M}\right.$ and $\left.10^{-7} \mathrm{M}\right)$ treatments decreased the content of all nutrients, except of $\mathrm{N}$ in the $10^{-8} \mathrm{M}$ treatment. The content of macronutrients in the IBA $\left(10^{-8} \mathrm{M}\right.$ and $\left.10^{-7} \mathrm{M}\right)$ treatments decreased in the range between $7.9-21.9 \%$ and $19.5-30.5 \%$, respectively and the content of micronutrients in the range between $13.7-52.6 \%$ and $25.0-37.3 \%$, respectively.

The content of all the selected macro- and micronutrients in the maize roots decreased in the Cd treatment $($ Tab. 3,4$)$. The content of Mn was the most affected, as it was decreased by $87.0 \%$ when compared to control. Other nutrients that were greatly influenced were $\mathrm{K}, \mathrm{Ca}, \mathrm{S}$, and $\mathrm{Zn}$. The application of $\mathrm{Cd}$ decreased their content in roots by almost $66.5 \%$ when compared to control. On the other hand, in the combined Cd+IBA treatment the content of all above-mentioned nutrients increased in comparison to Cd treatment. The exogenously-applied IBA $\left(10^{-9} \mathrm{M}\right)$ in the Cd+IBA treatment increased the 
content of $\mathrm{Mn}, \mathrm{S}$, and $\mathrm{Zn}$ by $24.6 \%, 98.4 \%$, and $49.4 \%$; respectively, while the content of both $\mathrm{K}$ and Ca increased by $75.8 \%$, when compared to Cd treatment.

\subsection{Heatmap analysis}

A heatmap with dendrograms was used to analyse and visualise the data from the study (Fig. 5). The dendrograms sort the treatments used in our study (control, IBA $\left(10^{-11} \mathrm{M}\right)$, IBA $\left(10^{-8} \mathrm{M}\right)$, IBA $\left.\left(10^{-7} \mathrm{M}\right), \mathrm{Cd}, \mathrm{Cd}+\mathrm{IBA}\right)$, as well as the parameters studied (growth parameters, activity of antioxidant enzymes, concentration of $\mathrm{H}_{2} \mathrm{O}_{2}$, content of nutrients) according to their similarity. The colouring clearly shows the increased activity of the antioxidant enzymes, the decreased growth parameters (except for primary root branching) and the content of nutrients in the Cd and Cd+lBA treatments, when compared to the control. The most sensitive nutrient in the $\mathrm{Cd}$ and $\mathrm{Cd}+\mathrm{IBA}$ treatments was $\mathrm{Mn}$.

The lateral dendrogram reveals the similarity between the treatments: control, IBA $\left(10^{-8} \mathrm{M}\right)$, IBA $\left(10^{-7} \mathrm{M}\right)$, and Cd+IBA, which are grouped in one big cluster. The control and the IBA $\left(10^{-8} \mathrm{M}\right)$ treatment are grouped in one smaller cluster, which confirms that IBA in $10^{-8} \mathrm{M}$ concentration may be termed a non-effective concentration. Second smaller cluster is formed by the IBA $\left(10^{-7} \mathrm{M}\right)$ and $\mathrm{Cd}+\mathrm{IBA}$ treatments, which share common features: the increase in the activity of antioxidant enzymes, decrease in the growth parameters and content of nutrients in comparison with the control. The IBA (10-11 $\mathrm{M}$ ) and $\mathrm{Cd}$ treatments are placed separately in the dendrogram from other treatments. The heatmap colouring indicates that the IBA (10-11 $\mathrm{M})$ treatment is characterized by the stimulation of maize growth and uptake of nutrients, and the decrease in the activity of antioxidant enzymes in comparison with the control. The heatmap shows that the $\mathrm{Cd}$ treatment negatively influenced the growth parameters, nutrients and caused an increase in the activity of antioxidant enzymes. It is noteworthy that there is a closer relationship between IBA $\left(10^{-7} \mathrm{M}\right)$ and Cd+IBA treatments than between the Cd+IBA and Cd treatments. Heatmap highlights the differences between the effects of Cd+IBA treatment and Cd treatment on the maize roots.

The upper dendrogram confirms the relationships between $\mathrm{H}_{2} \mathrm{O}_{2}$ and activity of three antioxidant enzymes (APX, CAT, SOD), since they are all grouped in one big cluster. The strong correlation was detected between APX and $\mathrm{H}_{2} \mathrm{O}_{2}$ as well as between CAT and SOD. The PR branching is the only parameter which remained practically without changes in all of the treatments, therefore it has a separate position in this cluster. The second big cluster is divided to three smaller clusters, and groups growth parameters and the content of nutrients. The first smaller cluster groups nutrients - Mn, $\mathrm{Cu}$, and $\mathrm{Zn}-\mathrm{in}$ which the closest relationships is between $\mathrm{Cu}$ and $\mathrm{Zn}$. The second small cluster groups the PR elongation and LR number, which are both the highest in the IBA $\left(10^{-11} \mathrm{M}\right)$ treatment. The third small cluster shows a correlation among fresh and dry weight, $\mathrm{P}, \mathrm{Mg}, \mathrm{K}, \mathrm{Ca}, \mathrm{S}, \mathrm{Fe}$, and N. Heatmap highlights the differences between the effects of Cd+IBA treatment and Cd treatment on the maize roots.

\section{Discussion}

Cadmium is highly toxic pollutant at very low concentration for all organisms, including plants (Hernandez-Baranda et al. 2019). It is non-degradable in the soil and its presence in plant cells results in the alterations of their growth, morphology, and development.

Some exogenous organic and inorganic substances have been recognized as alleviators of cadmium toxicity (Gangwar et al. 2004; Hernandez-Baranda et al. 2019). In the last years, phytohormones, mainly auxins, are promising substances that might reduce Cd toxicity and improve plant viability (Bali et al. 2019; Li et al. 2020; Zhang et al. 2020) because auxins control growth of the plant organs (Majda and Robert 2018). Endogenous auxin (IAA) activates ATPases in the plasma membrane, induces the efflux of $\mathrm{H}^{+}$to the cell wall, and causes extracellular acidification and the activation of enzymes such as expansins, endotransglucosylases/hydrolases and cell wall-loosening enzymes (Perrot-Rechenmann 2010; Lehman et al. 2017).

The exogenous application of auxins affects plant growth via endogenous IAA levels by modifying the metabolism of IAA and changing their conjugations with other molecules (Štefančič et al. 2007). The effects of auxins are highly dependent on their concentration. Very low concentrations of exogenous auxins do not cause these modifications. On the other hand, high concentrations of exogenous auxins do induce an increase in the internal levels of IAA (Nordström et al. 1991), which in turn increase the production of ethylene (Çakmakçı et al. 2020). High concentrations of ethylene stop plant cell division and slow cell expansion (Çakmakçı et al. 2020) by alkalization of the apoplast, which subsequently decreases the enzyme activity in the cell wall (Majda and Robert 2018). Similarly, we observed that a high concentration of IBA (10-7 M) inhibited maize growth while a low concentration $\left(10^{-11} \mathrm{M}\right)$ had a stimulating effect.

As mentioned above, exogenously-applied auxins also alleviate the toxic effects of Cd (Bashri and Prasad 2016) and improve the tolerance of plants to stress (Demescová and Tamás 2019; Singh et al. 2021). The presence of Cd in plant cells has a damaging effects on biomolecules, which are important for many physiological processes such as plant growth and development, photosynthesis, respiration, and nutrient uptake (Rizwan et al. 2016). Cd in short term, as well as in long term treatments (Zhu et al. 2013; Demecsová and Tamás 2019) decreases the internal level of auxin (IAA) because it induces IAA degradation by stimulating the activity of IAA-oxidase (Bashri and Prasad 2016). Cd also alters the expression of several important auxin biosynthetic and catabolic genes (Asgher et al. 2015). Thus, the negative effects of $\mathrm{Cd}$ on root growth determined in our experiment might also be connected to these processes. In our study, exogenously-applied IBA might have increased the internal level of auxin (previously reduced under the Cd treatment), which resulted in stimulation of the plant growth. The need to increase the internal level of auxin concentrations in the roots might explain the differences between the most efficient concentration of IBA under non-stress conditions $\left(10^{-11} \mathrm{M}\right)$ and the most efficient concentration of IBA under Cd stress $\left(10^{-9} \mathrm{M}\right)$. 
The molecules of $\mathrm{H}_{2} \mathrm{O}_{2}$ are non-radical reactive oxygen species (ROS) and they originate from the process of cell respiration in the mitochondria (Černý et al. 2018). The low concentrations of $\mathrm{H}_{2} \mathrm{O}_{2}$ in the root cells act as signalling molecules and regulators of the expression of some genes, and in many aspects resemble phytohormones. A rise in the concentration of $\mathrm{H}_{2} \mathrm{O}_{2}$ damages cell membranes, as well as the processes of respiration, and indicates oxidative stress in plants (Bashri and Prasad 2016; Černý et al. 2018). Oxidative stress occurs in plants exposed to suboptimal growth conditions, e.g. the presence of pollutants.

Auxins have a close association with ROS (including $\mathrm{H}_{2} \mathrm{O}_{2}$ ) because these molecules are able to interact with each other (Mishra et al. 2017). This crosstalk is easily disturbed by changes in the concentrations of auxins or ROS, and can result in an impairment of plant growth and development. In our study, the highest concentration of exogenously-applied auxin inhibited root growth and increased not only the concentration of $\mathrm{H}_{2} \mathrm{O}_{2}$ but also the activities of APX and CAT. Similarly, Bashri and Prasad (2016) observed a higher concentration of $\mathrm{H}_{2} \mathrm{O}_{2}$ and elevated antioxidant enzyme activity after treatment of Trigonellafoenum-graecum L. seedlings with IAA in a concentration which inhibited their growth. Externally-applied auxin probably increases the internal level of auxin and subsequently changes the cellular oxidative status of the plant (Mishra et al. 2017), resulting in an increase in ROS production (Tyburski et al. 2009; Bashri and Prasad 2016). Hence, the balance between produced-ROS and scavenged-ROS is disturbed and the root cells activate antioxidant enzymes (Demecsová and Tamás 2019). In our experiment, the stimulatory concentration of IBA (10-11 M) did not affect the concentration of $\mathrm{H}_{2} \mathrm{O}_{2}$ and decreased the activity of all the enzymes studied. El-Gaied et al. (2013) also observed a decrease in SOD, CAT and TPX gene expression after treatment with IAA and IBA in stimulatory concentrations. On the other hand, Bashri and Prasad (2016) observed an increase in the activities of SOD, APX, and CAT despite a reduction in the concentration of $\mathrm{H}_{2} \mathrm{O}_{2}$. The effects of auxin on the activity of antioxidant enzymes depended not only on the concentrations used, but also on the type of the auxin used (El-Gaied et al. 2013), and the age of the plants (Wang et al. 2007). Various activities were also found in the different zones of the primary root (Tyburski et al. 2009). The plant species, its phenotype, and its defence mechanisms possibly play an important role in the reaction of antioxidant enzymes to the exogenously-applied auxin.

In our experiments, the presence of $\mathrm{Cd}$ in the maize roots increased the concentration of $\mathrm{H}_{2} \mathrm{O}_{2}$ and subsequently the activity of antioxidant enzymes: SOD, CAT, and APX. The same results were ascertained in plants treated with toxic metals (Singh et al. 2010). All three enzymes are the first line of defence against oxidative stress (Mittler 2002) because they are responsible for the maintenance of the steady-state level of superoxide radicals and $\mathrm{H}_{2} \mathrm{O}_{2}$ (Mittler 2002).

In our experiments, the presence of IBA in combination with $\mathrm{Cd}$ in the substrate decreased the concentration of $\mathrm{H}_{2} \mathrm{O}_{2}$, as well as the activity of SOD, CAT, and APX, when compared to the Cd treatment. The addition of IBA to the medium might have alleviated the toxicity of Cd in two possible ways. The first way is that IBA could have scavenged the Cd in the cytoplasm. It is known that exogenous auxin can act as a chelating agent (Singh et al. 2021) because auxin occurs in a deprotonated form in the cytoplasm, which has a high affinity to $\mathrm{Cd}$. The second way is that exogenously-applied auxin probably supplements the reduced internal levels of auxin, which can be involved in the signalling pathways of the defence mechanisms (Demecsová and Tamás 2019). The transport and localization of auxin are important for the biosynthesis of metal-binding ligands, phytochelatins, and glutathione (Singh et al. 2021). The theory about enhanced immobilization of free Cd is also supported by our results. Even though that the exogenously-applied IBA did not affect the accumulation of $\mathrm{Cd}$ in the roots, the $\mathrm{Cd}+\mathrm{IBA}$ treated plants were significantly more viable than the Cd treated plants. Similar effects of IBA on the Cd accumulation in Stellaria media roots was observed by Lin et al. (2018). In addition to the concentration of auxin used (Lin et al. 2018; Ran et al. 2020), the effects of auxin on the accumulation of $\mathrm{Cd}$ in the plant roots depend also on its type. Natural auxin, IAA, in plants of wheat Triticum aestivum L. (Agami and Mohamed 2013) and Cyphomandra betacea (Li et al. 2020) decreased Cd concentration. On the other hand, the synthetic auxin 1-naphthaleneacetic acid (NAA) increased the concentration of Cd in Arabidopsis thaliana (Zhu et al. 2013).

Auxin can significantly affect the uptake and the content of some nutrients by affecting proton pump ATPase (San-Francisco et al. 2005). In our study, the IBA in the stimulatory concentration $\left(10^{-11} \mathrm{M}\right)$ induced the uptake and accumulation of all mineral nutrients as opposed to the IBA in the noneffective $\left(10^{-8} \mathrm{M}\right)$ and inhibitory $\left(10^{-7} \mathrm{M}\right)$ concentrations, which decreased their content in roots. The changes in the uptake and accumulation of mineral nutrients in the roots after IAA treatment were also ascertained in Capsicum annuum, Medicago sativa and Zea mays (San-Francisco et al. 2005; López et al. 2007; Wang et al. 2007). In all three plants they observed significant changes, mainly in the concentrations of $\mathrm{K}$, Ca, Mg, Mn, and Zn. They have not detected any changes in the content of N, P, S, and Fe. Auxin probably influences mainly the elements that are involved in the growth of roots or the biosynthesis of auxin. The change in the uptake of these elements caused by auxins might depend on the plant species and/or duration of auxin exposure. The effects of IBA on the accumulation of mineral nutrients in the roots have not yet been studied.

The present study confirms that $\mathrm{Cd}$ affects the uptake of macro- and micronutrients. We ascertained that Cd treatment caused an exceptionally high decrease in the content of $\mathrm{Mn}$ compared to the control. Furthermore, the content of the nutrients S, Zn, Ca, and K was also highly reduced. The reductions in the content of $\mathrm{N}, \mathrm{Cu}, \mathrm{Fe}, \mathrm{P}$, and $\mathrm{Mg}$ were lower. $\mathrm{Cd}$ enters the root cell through essential nutrient transporters (for more information, see Huang et al. 2020). Higher concentrations of $\mathrm{Cd}$ in the soil increase the competition with essential nutrients for transporters present at the root surface, thus decreasing their uptake. Our results also show that the $\mathrm{Cd}+\mathrm{IBA}$ treatment increased the uptake and accumulation of all nutrients. Changes in the uptake of mineral nutrients in the stressed plants of Medicago sativa, and of Zea mays after IAA treatments, were also studied by López et al. (2007) and Wang et al. (2007). López et al. (2007) did not determine any significant changes caused by the IAA treatment in the plants stressed by Pb. Wang et al. (2007) found that exogenously-applied auxin decreased the concentrations of $\mathrm{K}$ and $\mathrm{Mn}$ after long treatment with auxin. The effects of auxin depend not only on the concentration used and the period of the exposure (Wang et al. 2007), but also on the concentration of the toxic metal (López et al. 
2007). In both mentioned studies, the effects of IAA (in the used concentration) were not linked with growth parameters as opposed to our study, in which the effects of both stimulatory and inhibitory concentrations of IBA are supported by the results of maize growth.

The heatmap shows the differences between the effects of $\mathrm{Cd}, \mathrm{Cd}+\mathrm{IBA}$ and IBA $\left(10^{-11} \mathrm{M}\right)$. The negative effects of Cd on the growth parameters might be associated with a strong increase in the concentration of $\mathrm{H}_{2} \mathrm{O}_{2}$, the activation of antioxidant enzymes, and a decrease in the content of micro- and macronutrients. On the other hand, the positive effects of $\mathrm{Cd}+\mathrm{IBA}$ can be linked with increased content of mineral nutrients and decreased activity of antioxidant enzymes. Moreover, the positive effect of IBA $\left(10^{-11} \mathrm{M}\right)$ on the growth parameters and content of nutrients in comparison with the control is clearly visible.

Although Cd emissions to the environment had been considerably reduced in the last few years, the excess of Cd in soils and water sources still persists. Multiple health and environmental agencies had classified $\mathrm{Cd}$ and its compounds as carcinogenic, toxic and highlighted the importance of its study for the society. Different important crops still grow on sites with elevated risk of Cd-exposure; hence, WHO (World Health Organisation) has considered Cd as food pollutant. In the present study, we investigated the effects of a possible environmental-friendly biostimulant - auxin - on the maize that grew in the presence of $\mathrm{Cd}$. The important results of our study show, that IBA stimulates plant growth during Cd-stress via the activation of antioxidant enzymes and preservation of nutrient homeostasis in the roots. Treatment with a stimulatory concentration of IBA ameliorated the negative effects of Cd on the tissue and increased the production of biomass. However, the overall concentration of $\mathrm{Cd}$ in the root tissue was not influenced, which suggests that auxins influence the compartmentalization of this heavy metal in the cells. These results will aid in the selection of the appropriate green stimulant used for the elevation of plant growth in soils with different concentrations of toxic elements. It seems that usage of auxins is more suitable for the removal of Cd from the soils than for the restriction of Cd uptake to the root.

\section{Conclusion}

Our results show, that exogenously-applied IBA can alleviate $\mathrm{Cd}$ toxicity in maize plants. The presence of Cd in the substrate decreased the root growth parameters and the content of all selected nutrients; however, it increased the activity of selected antioxidant enzymes. Only the application of IBA in $10^{-}$

${ }^{9} \mathrm{M}$ concentration ameliorated the toxic effects of $\mathrm{Cd}$ in the plants. The positive effect of IBA during Cd stress might be connected to the decreased concentration of $\mathrm{H}_{2} \mathrm{O}_{2}$ and to the decreased activity of selected antioxidant enzymes, and increased uptake of essential nutrients. Effect of sole IBA application on plants depends on the concentration used, because it may act as inhibitor of plant growth and inducer of oxidative stress (IBA in the concentration $10^{-7} \mathrm{M}$ ) or as stimulator of growth (IBA in the concentrations $10^{-9} \mathrm{M}, 10^{-10} \mathrm{M}$, and $10^{-11} \mathrm{M}$ ). IBA in the $10^{-8} \mathrm{M}$ concentration did not affect any of the observed growth parameters and did not induce oxidative stress, but it decreased content of mineral nutrients. The heatmap clearly showed the strong stimulatory effects of IBA $\left(10^{-11} \mathrm{M}\right)$ on maize growth and ameliorative effect of IBA in $10^{-9} \mathrm{M}$ concentration on plant growth and other measured parameters compared to the $\mathrm{Cd}$ treatment.

\section{Abbreviations}

APX, ascorbate peroxidase; CAT, catalase; IAA, indole-3-acetic acid; IBA, indole-3-butyric acid; PR, primary roots; ROS, reactive oxygen species; SOD, superoxide dismutase.

\section{Declarations}

Ethical approval: This article does not contain any studies with human participants or animals performed by any of the authors.

Consent to participate: The authors consent to participate in this research study.

Consent to publish: The authors consent to publish the current research in Environmental Pollution and Science Research.

Availability of data and materials: The data, which support the findings of this study, are available from the corresponding author upon reasonable request.

Competing interests: The authors declare that they have no known competing financial interests or personal relationships that could have appeared to influence the work reported in this paper.

Funding: This study was funded by Scientific Grant Agency of the Ministry of Education of the Slovak Republic and the Academy of Sciences VEGA no. 2/0105/18.

Authors' contributions: KŠ and ZV conceived the present idea and designed the study. KŠ and EL carried out the experiments. KŠ, EL, KK, and ZV analysed the data. DK made and described a heatmap. KŠ and ZV wrote the manuscript with input from EL, DK and KK. All authors provided critical comments.

Acknowledgements: This work was financially supported by the Scientific Grant Agency of the Ministry of Education of the Slovak Republic and the Academy of Sciences VEGA no. 2/0105/18. 


\section{References}

1. Agami RA, Mohamed GF (2013) Exogenous treatment with indole-3-acetic acid and salicylic acid alleviates cadmium toxicity in wheat seedlings. Ecotoxicol Environ Saf 94:164-171. https://doi.org/10.1016/j.ecoenv.2013.04.013

2. Anjum SA, Tanveer M, Hussain S et al (2015) Cadmium toxicity in Maize (Zea mays L.): consequences on antioxidative systems, reactive oxygen species and cadmium accumulation. Environ Sci Pollut Res 22:17022-17030. https://doi.org/10.1007/s11356-015-4882-z

3. Asgher M, Khan MIR, Anjum NA, Khan NA (2015) Minimising toxicity of cadmium in plants-role of plant growth regulators. Protoplasma 252:399413. https://doi.org/10.1007/s00709-014-0710-4

4. Bali AS, Sidhu GPS, Kumar V, Bhardwaj R (2018) Mitigating Cadmium Toxicity in Plants by Phytohormones. In: Hasanuzzaman M, Prasad MNV, Fujita M (eds) Cadmium Toxicity and Tolerance in Plants: From Physiology to Remediation. Academic Press, London, pp 375-396

5. Bashri G, Prasad SM (2016) Exogenous IAA differentially affects growth, oxidative stress and antioxidants system in Cd stressed Trigonella foenum-graecum L. seedlings: Toxicity alleviation by up-regulation of ascorbate-glutathione cycle. Ecotoxicol Environ Saf 132:329-338. https://doi.org/10.1016/j.ecoenv.2016.06.015

6. Bradford MM (1976) A rapid and sensitive method for the quantitation of microgram quantities of protein utilizing the principle of protein-dye binding. Anal Biochem 72:248-254. https://doi.org/10.1016/0003-2697(76)90527-3

7. Çakmakçı R, Mosber G, Milton AH et al (2020) The Effect of Auxin and Auxin-Producing Bacteria on the Growth, Essential Oil Yield, and Composition in Medicinal and Aromatic Plants. Curr Microbiol 77:564-577. https://doi.org/10.1007/s00284-020-01917-4

8. Claiborne A (1985) Catalase activity. In: Greenwald RA (ed) Handbook of Methods for Oxygen Radical Research. CRC Press, Boca Raton, pp 283284

9. Clemens A, Aarts MG, Thomine S et al (2013) Plant science: the key to prevent slow cadmium poisoning. Trend Plant Sci 18:92-99. https://doi.org/10.1016/j.tplants.2012.08.003

10. Černý M, Habánová H, Berka M et al (2018) Hydrogen peroxide: Its role in plant biology and crosstalk with signalling networks. Int J Mol Sci 19:2812. https://doi.org/10.3390/ijms19092812

11. Demecsová L, Tamás L (2019) Reactive oxygen species, auxin and nitric oxide in metal-stressed roots: toxicity or defence. Biometals 32:717-744. https://doi.org/10.1007/s10534-019-00214-3

12. El-Gaied LF, Abu El-Heba GA, El-Sherif NA (2013) Effect of growth hormones on some antioxidant parameters and gene expression in tomato. GM Crops Food 4:67-73. https://doi.org/10.4161/gmcr.24324

13. Gangwar S, Singh VP, Tripathi DK et al (2014) Plant Responses to Metal Stress: The Emerging Role of Plant Growth Hormones in Toxicity Alleviation. In: Ahmad P, Rasool S (eds) Emerging Technologies and Management of Crop Stress Tolerance. Academic Press, London, pp 215-248

14. Garg N, Manchanda G (2009) ROS generation in plants: Boon or bane? Plant Biosyst 143:81-96. https://doi.org/10.1080/11263500802633626

15. Hernandez-Baranda Y, Rodriguez-Hernandez P, Pena-Icart M et al (2019) Toxicity of Cadmium in plants and strategies to reduce its effects. Case study: The tomato. Cultivos Tropicales 40:e10

16. Hodges DM, Andrews CJ, Johnson DA, Hamilton RI (1997) Antioxidant enzyme responses to chilling stress in differentially sensitive inbred maize lines. J Exp Bot 48:1105-1113. https://doi.org/10.1093/jxb/48.5.1105

17. Huang X, Duan S, Wu Q et al (2020) Reducing cadmium accumulation in plants: Structure-function relations and tissue-specific operation of transporters in the spotlight. Plants 9:223. https://doi.org/10.3390/plants9020223

18. Järup L, Åkesson A (2009) Current status of cadmium as an environmental health problem. Toxicol Appl Pharmacol 238:201-208

19. Lehman TA, Smertenko A, Sanguinet KA (2017) Auxin, microtubules, and vesicle traffcking: Conspirators behind the cell wall. J Exp Bot 68:33213329. https://doi.org/10.1093/jxb/erx205

20. Li Z, Zhu J, Wang Y et al (2020) Effects of exogenous indole acetic acid on growth and cadmium accumulation of Cyphomandra betacea seedlings. Int J Environ Anal Chem. https://doi.org/10.1080/03067319.2020.1726336

21. Lin L, Ma Q, Wang J et al (2018) Effects of indole-3-butytric acid (IBA) on growth and cadmium accumulation in the accumulator plant Stellaria media. Environ Prog Sustain Energy 37:733-737. https://doi.org/10.1002/ep.12746

22. López ML, Peralta-Videa JR, Benitez T et al (2007) Effects of lead, EDTA, and IAA on nutrient uptake by alfalfa plants. J Plant Nutr 30:1247-1261. https://doi.org/10.1080/01904160701555143

23. Madamanchi NR, Donahue JL, Cramer CL et al (1994) Differential response of Cu,Zn superoxide dismutases in two pea cultivars during a short-term exposure to sulfur dioxide. Plant Mol Biol 26:95-103. https://doi.org/10.1007/BF00039523

24. Majda M, Robert S (2018) The role of auxin in cell wall expansion. Int J Mol Sci 19:951. https://doi.org/10.3390/ijms19040951

25. Mishra S, Srivastava V, Mehrotra S, Quadri SN (2017) The regulation of plant development: Cross-talk of reactive oxygen species and plant hormones. In: Singh VP, Singh S, Tripathi DK et al (eds) Reactive Oxygen Species in Plants: Boon Or Bane - Revisiting the Role of ROS. Wiley, New York, pp 243-260. https://doi.org/10.1002/9781119324928.ch13

26. Mittler R (2002) Oxidative stress, antioxidants and stress tolerance. Trends Plant Sci 7:405-410. https://doi.org/10.1016/S1360-1385(02)02312-9

27. Nakano Y, Asada K (1981) Hydrogen peroxide is scavenged by ascorbate-specific peroxidase in spinach chloroplasts. Plant Cell Physiol 22:867880. https://doi.org/10.1093/oxfordjournals.pcp.a076232

Page $8 / 13$ 
28. Nordström AC, Jacobs FA, Efiasson L (1991) Effect of exogenous indole-3-acetic acid and indole-3-butyric acid on internal levels of the respective auxins and their conjugation with aspartic acid during adventitious root formation in pea cuttings. Plant Physiol 96:856-861.

https://doi.org/10.1104/pp.96.3.856

29. Perrot-Rechenmann C (2010) Cellular responses to auxin: division versus expansion. Cold Spring Harb Perspect Biol 2:a001446. https://doi.org/10.1101/cshperspect.a001446

30. Core Team R (2020) R: a language and environment for statistical computing. R Foundation for Statistical Computing, Vienna, Austria. https://www.R-proje ct.org/

31. Ran J, Zheng W, Wang $\mathrm{H}$ et al (2020) Indole-3-acetic acid promotes cadmium (Cd) accumulation in a Cd hyperaccumulator and a nonhyperaccumulator by different physiological responses. Ecotoxicol Environ Saf 191:110213. https://doi.org/10.1016/j.ecoenv.2020.110213

32. Rizwan M, Ali S, Abbas T et al (2016) Cadmium minimization in wheat: A critical review. Ecotoxicol Environ Saf 130:43-53. https://doi.org/10.1016/j.ecoenv.2016.04.001

33. San-Francisco S, Houdusse F, Zamarreño AM et al (2005) Effects of IAA and IAA precursors on the development, mineral nutrition, IAA content and free polyamine content of pepper plants cultivated in hydroponic conditions. Sci Hortic (Amsterdam) 106:38-52. https://doi.org/10.1016/j.scienta.2005.03.006

34. Singh H, Bhat JA, Singh VP et al (2021) Auxin metabolic network regulates the plant response to metalloids stress. J Hazard Mater $405: 124250$. https://doi.org/10.1016/j.jhazmat.2020.124250

35. Singh S, Singh S, Ramachandran V, Eapen S (2010) Copper tolerance and response of antioxidative enzymes in axenically grown Brassica juncea (L.) plants. Ecotoxicol Environ Saf 73:1975-1981. https://doi.org/10.1016/j.ecoenv.2010.08.020

36. Šípošová K, Kollárová K, Lišková D, Vivodová Z (2019) The effects of IBA on the composition of maize root cell walls. J Plant Physiol $239: 10-17$. https://doi.org/10.1016/j.jplph.2019.04.004

37. Štefančič M, Štampar F, Veberič R, Osterc G (2007) The levels of IAA, IAAsp and some phenolics in cherry rootstock "GiSelA 5" leafy cuttings pretreated with IAA and IBA. Sci Hortic (Amsterdam) 112:399-405. https://doi.org/10.1016/j.scienta.2007.01.004

38. Sun X, Li J (2013) Pairheatmap: comparing expression profiles of gene groups in heatmaps. Comput Methods Prog Biomed 112:599-606. http://dx.doi.org/10.1016/j.cmpb.2013.07.010

39. Tognetti VB, Mühlenbock P, van Breusegem F (2012) Stress homeostasis - the redox and auxin perspective. Plant Cell Environ 35:321-333. https://doi.org/10.1111/j.1365-3040.2011.02324.x

40. Tyburski J, Dunajska K, Mazurek P et al (2009) Exogenous auxin regulates H2O2 metabolism in roots of tomato (Lycopersicon esculentum Mill.) seedlings affecting the expression and activity of CuZn-superoxide dismutase, catalase, and peroxidase. Acta Physiol Plant 31:249-260. https://doi.org/10.1007/s11738-008-0225-8

41. Velikova V, Yordanov I, Edreva A (2000) Oxidative stress and some antioxidant systems in acid rain-treated bean plants protective role of exogenous polyamines. Plant Sci 151:59-66. https://doi.org/10.1016/S0168-9452(99)00197-1

42. Wagner GJ (1993) Accumulation of cadmium in crop plants and its consequences to human health. In: Sparks DL (ed) Advances in Agronomy. Elsevier Academic Press Inc, San Diego, pp 173-212

43. Wang H, Shan X, quan, Wen B et al (2007) Effect of indole-3-acetic acid on lead accumulation in maize (Zea mays L.) seedlings and the relevant antioxidant response. Environ Exp Bot 61:246-253. https://doi.org/10.1016/j.envexpbot.2007.06.004

44. Zhang C, He Q, Wang M et al (2020) Exogenous indole acetic acid alleviates Cd toxicity in tea (Camellia sinensis). Ecotoxicol Environ Saf 190:110090. https://doi.org/10.1016/j.ecoenv.2019.110090

45. Warnes GR, Bolker B, Bonebakker L et al (2020) gplots: various R programming tools for plotting data. R package version 3.0.3. https://CRAN.R-proje ct.org/packa ge $=$ gplots

46. Zhu XF, Wang ZW, Dong F et al (2013) Exogenous auxin alleviates cadmium toxicity in Arabidopsis thaliana by stimulating synthesis of hemicellulose 1 and increasing the cadmium fixation capacity of root cell walls. J Hazard Mater 263:398-403.

https://doi.org/10.1016/j.jhazmat.2013.09.018

\section{Tables}

Table 1

Growth parameters of maize plants cultivated in Hoagland solution (control) and in the same medium supplemented with IBA in various concentrations $\left(10^{-12}-10^{-7} \mathrm{M}\right)$. The data are presented as means \pm standard error $(n=45)$. PR - primary roots, $L R-$ lateral roots. Different letters denote statistically significant differences in the parameters between the treatments at $P<0.05$ according to Tukey test. 


\begin{tabular}{|c|c|c|c|c|c|}
\hline & Elongation of PR $[\mathrm{cm}]$ & Branching of PR [\%] & Number of LR & Fresh weight [mg] & Dry weight [mg] \\
\hline Control & $19.9 \pm 1.0^{\mathrm{bc}}$ & $66.5 \pm 0.9^{a}$ & $116.0 \pm 4.9^{b}$ & $795.0 \pm 27^{b}$ & $41.0 \pm 1^{\mathrm{cd}}$ \\
\hline $10^{-12} \mathrm{M}$ IBA & $35.0 \pm 0.7^{e}$ & $80.5 \pm 0.6^{d}$ & $195.7 \pm 6.3^{\text {de }}$ & $766.6 \pm 34^{\mathrm{b}}$ & $39.9 \pm 1^{\mathrm{bcd}}$ \\
\hline $10^{-11} \mathrm{M}$ IBA & $32.0 \pm 1.2^{\mathrm{e}}$ & $80.6 \pm 1.1^{d}$ & $212.5 \pm 4.8^{e}$ & $1023.9 \pm 34^{c}$ & $46.5 \pm 2^{d}$ \\
\hline $10^{-10} \mathrm{M}$ IBA & $25.9 \pm 1.3^{d}$ & $80.0 \pm 0.8^{d}$ & $190.2 \pm 6.6^{d}$ & $937.3 \pm 42^{b c}$ & $41.4 \pm 1^{\mathrm{cd}}$ \\
\hline $10^{-9} \mathrm{M}$ IBA & $23.0 \pm 0.7^{\mathrm{cd}}$ & $75.2 \pm 0.8^{c}$ & $141.4 \pm 5.1^{c}$ & $834.2 \pm 54^{b}$ & $39.0 \pm 1^{b c}$ \\
\hline $10^{-8} \mathrm{M}$ IBA & $18.1 \pm 0.8^{b}$ & $71.1 \pm 1.4^{\mathrm{b}}$ & $112.8 \pm 4.7^{b}$ & $749.3 \pm 43^{b}$ & $34.3 \pm 2^{\mathrm{ab}}$ \\
\hline $10^{-7} \mathrm{M}$ IBA & $5.4 \pm 0.2^{\mathrm{a}}$ & $64.8 \pm 0.8^{a}$ & $76.1 \pm 4.3^{a}$ & $572.4 \pm 20^{a}$ & $30.7 \pm 1^{a}$ \\
\hline
\end{tabular}

\section{Table 2}

Growth parameters of maize plants cultivated in Hoagland solution (control) and in the same medium supplemented with Cd (50 mM) or Cd and IBA in various concentrations $\left(10^{-12}-10^{-7} \mathrm{M}\right)$. The data are presented as means \pm standard error $(n=45)$. PR - primary roots, $L R-$ lateral roots. Different letters denote statistically significant differences in the parameters between the treatments at $P<0.05$ according to Tukey test.

\begin{tabular}{|c|c|c|c|c|c|}
\hline & Elongation of PR [mm] & Branching of PR [\%] & Number of LR & Fresh weight [mg] & Dry weight \\
\hline Control & $20.9 \pm 0.8^{c}$ & $66.6 \pm 0.5^{a}$ & $115.5 \pm 8.1^{c}$ & $800.2 \pm 45^{d}$ & $40.6 \pm 2^{d}$ \\
\hline Cd & $8.2 \pm 0.2^{\mathrm{a}}$ & $72.0 \pm 0.5^{b}$ & $55.3 \pm 1.0^{a}$ & $409.6 \pm 37^{a b}$ & $21.8 \pm 2^{\mathrm{ab}}$ \\
\hline $\mathrm{Cd}+10^{-12} \mathrm{M}$ IBA & $8.5 \pm 0.2^{a}$ & $78.4 \pm 1.5^{c}$ & $57.0 \pm 1.3^{\mathrm{a}}$ & $433.8 \pm 23^{b}$ & $26.5 \pm 1^{b}$ \\
\hline $\mathrm{Cd}+10^{-11} \mathrm{M}$ IBA & $7.8 \pm 0.2^{a}$ & $78.2 \pm 1.4^{\mathrm{c}}$ & $61.8 \pm 0.6^{a b}$ & $460.5 \pm 25^{b}$ & $26.2 \pm 1^{b c}$ \\
\hline $\mathrm{Cd}+10^{-10} \mathrm{M}$ IBA & $8.1 \pm 0.2^{a}$ & $71.2 \pm 1.0^{\mathrm{b}}$ & $60.5 \pm 1.5^{\mathrm{ab}}$ & $454.2 \pm 12^{\mathrm{abc}}$ & $25.0 \pm 1^{a b}$ \\
\hline $\mathrm{Cd}+10^{-9} \mathrm{M}$ IBA & $10.8 \pm 0.5^{b}$ & $66.2 \pm 1.1^{\mathrm{a}}$ & $72.3 \pm 1.0^{\mathrm{b}}$ & $623.0 \pm 29^{c}$ & $34.4 \pm 1^{\mathrm{cd}}$ \\
\hline $\mathrm{Cd}+10^{-8} \mathrm{M}$ IBA & $7.9 \pm 0.2^{\mathrm{a}}$ & $73.8 \pm 0.8^{b c}$ & $56.8 \pm 0.8^{a}$ & $306.5 \pm 18^{a}$ & $21.1 \pm 1^{\mathrm{ab}}$ \\
\hline $\mathrm{Cd}+10^{-7} \quad \mathrm{M}$ IBA & $7.3 \pm 0.2^{a}$ & $72.4 \pm 0.4^{b}$ & $55.4 \pm 0.7^{a}$ & $347.8 \pm 34^{a b}$ & $17.7 \pm 1^{a}$ \\
\hline
\end{tabular}

\section{Table 3}

The content of macronutrients in maize roots of one plant treated without/with $\mathrm{Cd}$. The data are presented as means \pm standard error ( $\mathrm{n}=9$ ). Different letters denote statistically significant differences in the parameters between the treatments at $P<0.05$ according to Tukey test.

\begin{tabular}{|c|c|c|c|c|c|c|c|c|c|c|c|c|c|c|c|c|c|c|}
\hline \multirow[b]{2}{*}{ Control } & \multicolumn{3}{|c|}{$\mathrm{N}$ [mg] } & \multicolumn{3}{|l|}{$P[\mu \mathrm{g}]$} & \multicolumn{3}{|c|}{$\mathrm{K}$ [mg] } & \multicolumn{3}{|l|}{$\mathrm{Ca}[\mu \mathrm{g}]$} & \multicolumn{3}{|l|}{$S$ [ $\mu \mathrm{g}]$} & \multicolumn{3}{|l|}{$\mathrm{Mg}[\mu \mathrm{g}]$} \\
\hline & 2.03 & \pm & $0.02^{d}$ & 470.54 & \pm & $2.12^{\mathrm{e}}$ & 1.90 & \pm & $0.02^{\mathrm{e}}$ & 716.50 & \pm & $3.90^{d}$ & 217.74 & \pm & $10.23^{d}$ & 267.27 & \pm & $1.73^{\mathrm{e}}$ \\
\hline $\begin{array}{l}10^{-11} \mathrm{M} \\
\text { IBA }\end{array}$ & 2.38 & \pm & $0.12^{\mathrm{e}}$ & 531.50 & \pm & $3.22^{f}$ & 2.52 & \pm & $0.01^{f}$ & 761.59 & \pm & $2.75^{\mathrm{e}}$ & 252.97 & \pm & $4.97^{e}$ & 305.27 & \pm & $1.61^{f}$ \\
\hline $\begin{array}{l}10^{-8} \mathrm{M} \\
\text { IBA }\end{array}$ & 1.83 & \pm & $0.07^{d}$ & 398.75 & \pm & $21.03^{d}$ & 1.75 & \pm & $0.02^{d}$ & 564.51 & \pm & $26.2^{c}$ & 171.99 & \pm & $7.71^{c}$ & 208.68 & \pm & $3.39^{\circ}$ \\
\hline $\begin{array}{l}10^{-7} M \\
\text { IBA }\end{array}$ & 1.59 & \pm & $0.06^{c}$ & 367.38 & \pm & $3.71^{\mathrm{cd}}$ & 1.53 & \pm & $0.02^{c}$ & 544.36 & \pm & $9.11^{\mathrm{c}}$ & 156.21 & \pm & $9.20^{\mathrm{bc}}$ & 185.79 & \pm & $0.55^{\mathrm{b}}$ \\
\hline $\mathrm{Cd}$ & 0.80 & \pm & $0.01^{a}$ & 237.57 & \pm & $0.97^{a}$ & 0.66 & \pm & $0.01^{a}$ & 247.65 & \pm & $2.55^{a}$ & 68.46 & \pm & $3.05^{a}$ & 144.51 & \pm & $1.77^{\mathrm{a}}$ \\
\hline $\begin{array}{l}\mathrm{Cd}+10^{-9} \\
\mathrm{M} \text { IBA }\end{array}$ & 1.23 & \pm & $0.02^{b}$ & 356.50 & \pm & $4.19^{b}$ & 1.16 & \pm & $0.01^{b}$ & 435.58 & \pm & $2.26^{b}$ & 135.82 & \pm & $3.13^{b}$ & 224.71 & \pm & $2.81^{\mathrm{d}}$ \\
\hline
\end{tabular}




\section{Table 4}

The content of micronutrients in maize roots of one plant treated without/with Cd. The data are presented as means \pm standard error $(n=9)$. Different letters denote statistically significant differences in the parameters between the treatments at $P<0.05$ according to Tukey test.

\begin{tabular}{|c|c|c|c|c|c|c|c|c|c|c|c|c|}
\hline & $\mathrm{Fe}[\mu \mathrm{g}]$ & & & $M n[\mu g]$ & & & $\mathrm{Zn}[\mu \mathrm{g}$ & & & $\mathrm{Cu}[\mu$ & & \\
\hline Control & 689.26 & \pm & $11.82^{\mathrm{e}}$ & 115.48 & \pm & $0.34^{d}$ & 12.04 & \pm & $0.05^{e}$ & 3.78 & \pm & $0.02^{d}$ \\
\hline $10^{-11} \mathrm{M}$ IBA & 767.99 & \pm & $12.08^{f}$ & 124.47 & \pm & $0.55^{\mathrm{e}}$ & 14.36 & + & $0.16^{f}$ & 4.08 & \pm & $0.02^{\mathrm{e}}$ \\
\hline $10^{-8} \mathrm{M}$ IBA & 595.11 & \pm & $2.32^{d}$ & 76.10 & \pm & $1.32^{c}$ & 6.43 & \pm & $0.09^{c}$ & 1.79 & \pm & $0.02^{b}$ \\
\hline $10^{-7} \mathrm{M}$ IBA & 506.35 & \pm & $2.57^{c}$ & 75.42 & \pm & $0.27^{c}$ & 9.03 & \pm & $0.16^{d}$ & 2.37 & \pm & $0.02^{c}$ \\
\hline $\mathrm{Cd}$ & 295.03 & \pm & $4.90^{\mathrm{a}}$ & 14.98 & \pm & $0.14^{\mathrm{a}}$ & 4.01 & \pm & $0.03^{a}$ & 1.47 & \pm & $0.01^{\mathrm{a}}$ \\
\hline $\mathrm{Cd}+10^{-9} \mathrm{M}$ IBA & 455.11 & \pm & $0.93^{\mathrm{b}}$ & 18.66 & \pm & $0.24^{b}$ & 5.99 & \pm & $0.05^{\mathrm{b}}$ & 2.31 & \pm & $0.03^{c}$ \\
\hline
\end{tabular}

\section{Figures}

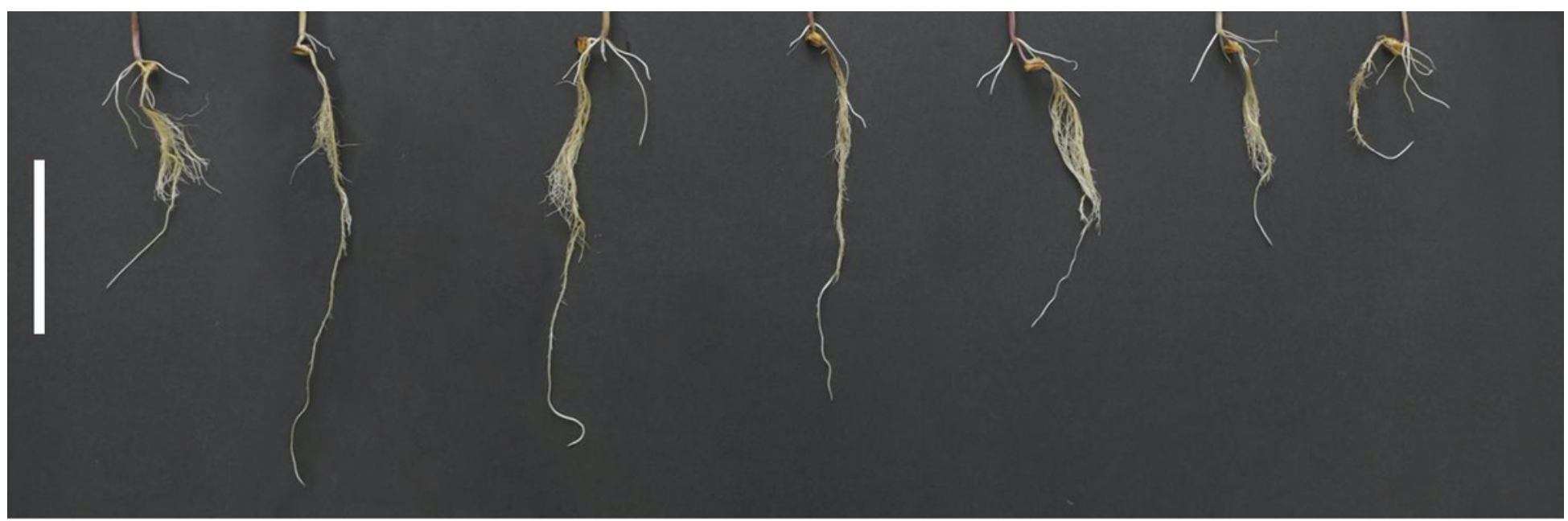

\section{Control $10^{-12} \mathrm{M}$ IBA $\quad 10^{-11} \mathrm{M}$ IBA $\quad 10^{-10} \mathrm{M}$ IBA $\quad 10^{-9} \mathrm{M}$ IBA $\quad 10^{-8} \mathrm{M}$ IBA $\quad 10^{-7} \mathrm{M}$ IBA}

\section{Figure 1}

The effects of IBA on the root morphology of plants. Scale bar is $10 \mathrm{~cm}$. 

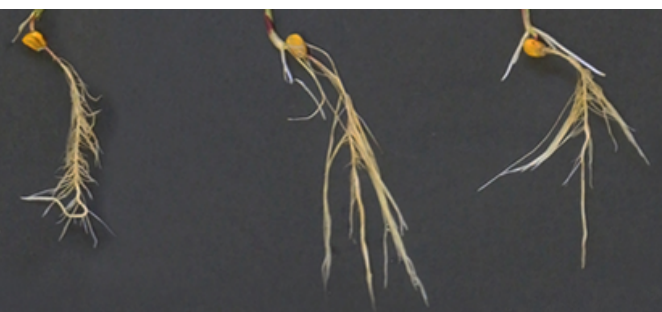

\section{Control \\ Cd \\ Cd + \\ Cd + \\ Cd + \\ Cd + \\ Cd + \\ Cd + $10^{-12}$ M IBA $10^{-11}$ M IBA $10^{-10}$ M IBA $\quad 10^{-9}$ M IBA $10^{-8}$ M IBA $10^{-7}$ M IBA}

Figure 2

The effects of IBA on the root morphology of plants treated with Cd. Scale bar is $10 \mathrm{~cm}$.
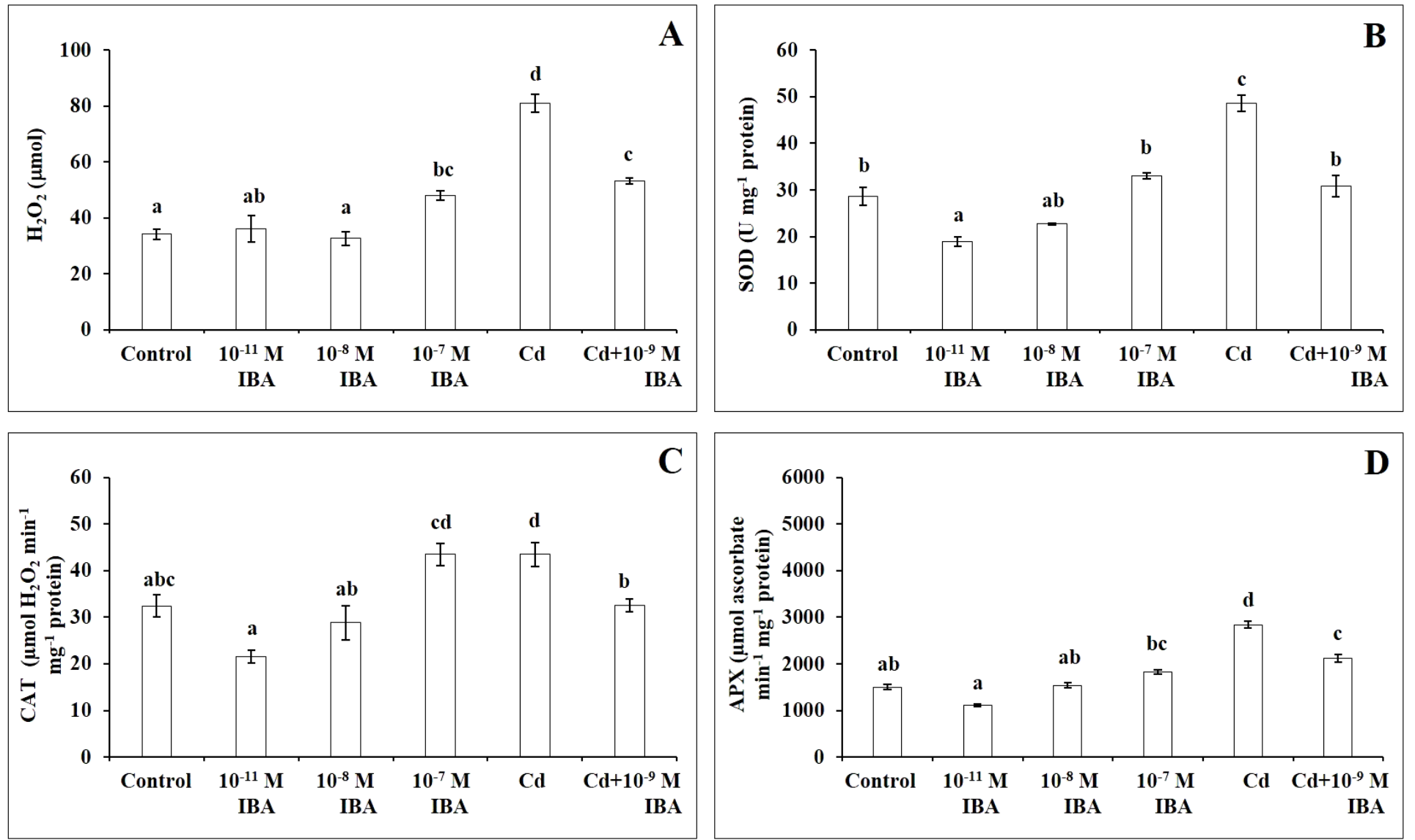

Figure 3

The concentration of H2O2 (A) and the activities of antioxidant enzymes SOD (B), CAT (C), APX (D) in the plants treated without/with Cd. The data are presented as means \pm standard error $(n=15)$. Different letters denote statistically significant differences in the parameters between the treatments at $P<$ 0.05 according to Tukey test. 


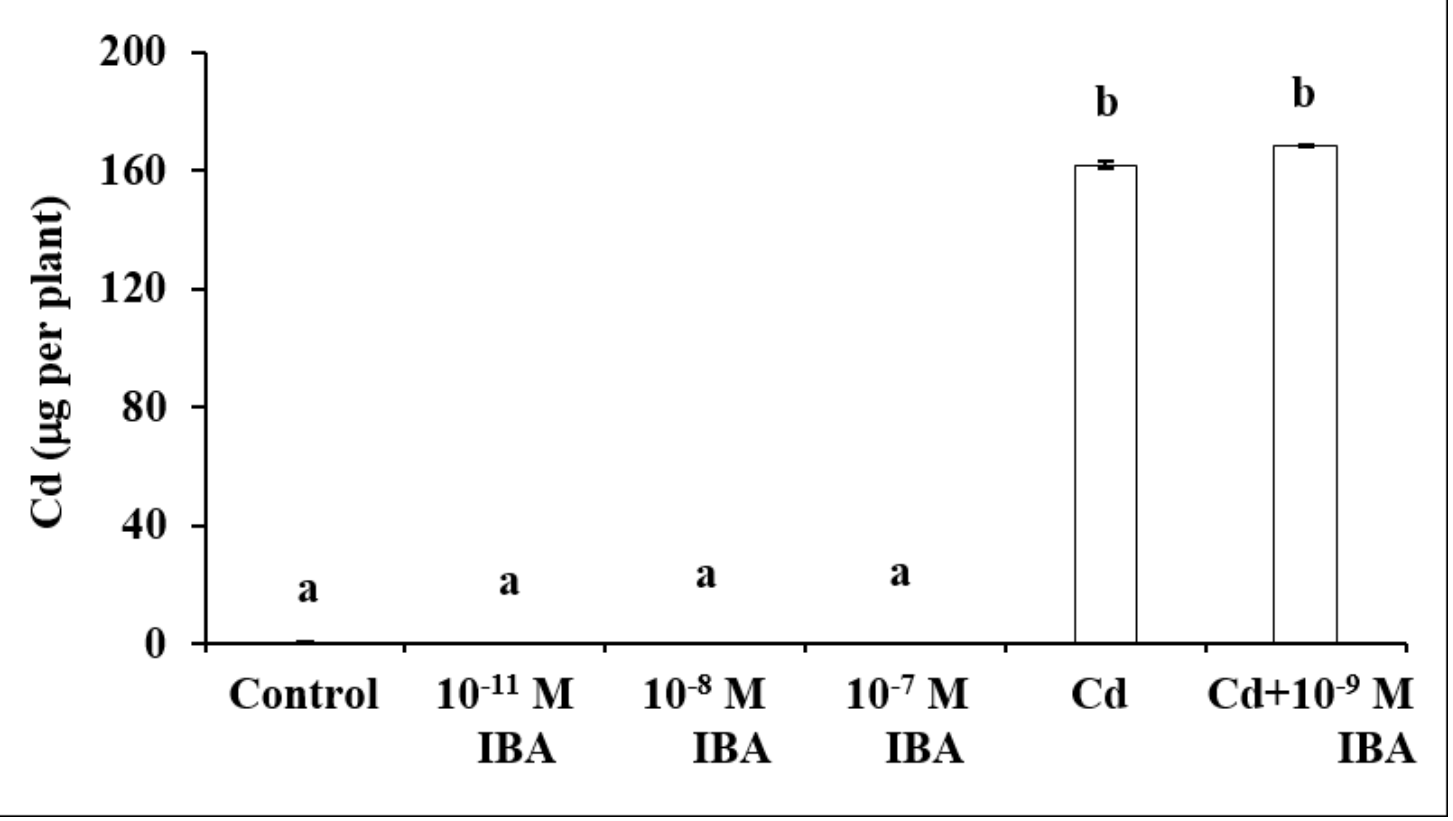

\section{Figure 4}

The content of $\mathrm{Cd}$ in maize roots of one plant treated without/with IBA. The data are presented as means \pm standard error ( $\mathrm{n}=5$ ). Different letters denote statistically significant differences in the parameters between the treatments at $\mathrm{P}<0.05$ according to Tukey test.

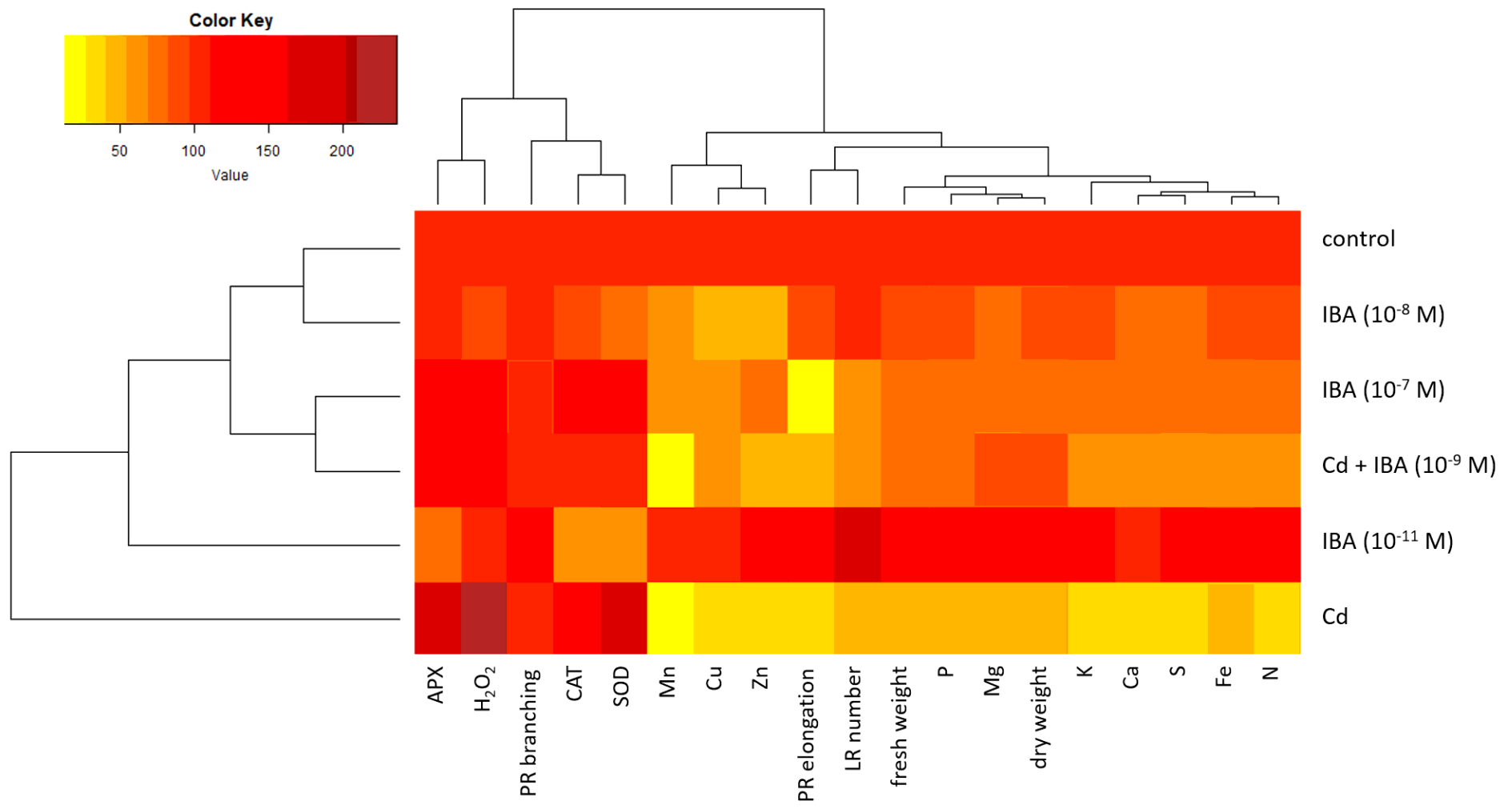

Figure 5

The heatmap analysis of the parameters studied in the treatments: control, IBA (10-11 M), IBA (10-8 M), IBA (10-7 M), Cd, Cd+IBA. The same colour indicates a similar value of the parameter. Every value of every parameter is expressed as a percentage of its corresponding control. PR elongation elongation of primary root; PR branching - branching of primary root; LR number - number of lateral roots; fresh weight - root fresh weight; dry weight - root dry weight. 